\title{
THE ASSET MANAGEMENT CONTRACT OF NATIONAL ASSETS IN HUNGARY
}

\author{
János Dúl ${ }^{1}$
}

DOI: https://doi.org/10.31410/ERAZ.2019.113

\begin{abstract}
The aim of the paper is to give a short outlook on asset management contract of the so-called national assets (this terminus covers all the assets of the Hungarian State and the local government according to Act CXCVI of 2011 on national assets). We would like to give a definition for asset management according to different views in legal and economical literature, after this we will present the current regulation of these special contracts with its subjects, its objects and the rights and obligations of each subject. We come to the conclusion: this act is considered to be a part of public law, but it consists of important regulation in connection with private law, and lots of rules can be understood only in the light of civil law.
\end{abstract}

Keywords: asset management, asset management contract, Hungary, national assets, public property management.

\section{INTRODUCTION - NOTION OF ASSET MANAGEMENT}

$\mathrm{T}$ he aim of this paper is to give a short outlook on asset management contract of the national assets in Hungarian law. First of all, we have to discuss the definition of asset management, its meaning as a legal institute.

We can meet with this terminus in Hungarian law in public law; it has a strong connection with the assets and their management of the Hungarian State and the local governments. Asset management is a complex task, and it depends on the composition of the assets, their characteristics, and the content of legal relation of the asset management, especially the rights and obligations of the administrator of estate. We cannot find so many scientific articles in the Hungarian legal literature related to asset management in order to define its notion. What we find at level of legal acts is in Act CXCVI of 2011 on national assets (hereinafter referred to as Nvt.), and these provisions refer mostly to the above mentioned rights and obligations of the administrator of estate who exercises the rights and obligations of the owner in almost the same way as the owner could do it. [1] To explain this "almost the same way", we can give an example: the administrator of estate is not allowed to dispose over the national asset and this person can encumber it only in limited extent. [2] The rights and obligations of the administrator of estate are not the same as the rights and obligations of the owner; it is enough to examine the direction of practicing the rights of the owner. The owner practices the rights for his or her benefit; and the administrator of estate practices the rights for the benefit of another person. [3]

There are more possible ways to define the notion of asset management and asset management contract; one of the most laconic definitions is that asset management contract is a legal relation in law of obligations between the owner and the administrator of estate in order to handle the asset management. [4] This definition is a proper starting point but we cannot get to know more about this legal institute; this is why we give more definitions:

National University of Public Service, H-1083 Budapest, Üllői út 82, Hungary 
a) Asset management is exercise of one or more rights and obligations of the owner (right to possess, right to use, right of beneficial enjoyment and the right to dispose over property) over things, group of things or other rights for the benefit of a person who must be different from the administrator of estate. [5] This approach is not proper in connection with national assets in current Hungarian legal regulation: for example, the right to dispose over property does not belong to the administrator of estate.

b) Another definition is that asset management is an activity practiced in the name of the owner instead of the owner. It is based on the intention of the owner, and its purpose is to exercise rights and obligations of the owner over the whole property of this person or on its certain part. [6]

c) According to Tamás Sárközy, asset management means basically the preservation of the assets, stopping or reducing the devaluation, furthermore, increasing value in economical approach. The administrator of estate is collaborator of the owner: the administrator of estate can be handled as accessory after the fact; since the administrator of estate exercises the rights and obligations of the owner over the whole property of this person or on its certain part. [7]

To draw some consequences deriving from these definitions, we can define asset management in this way: asset management is exercising one or more rights and obligations of the owner not by the owner, but for his or her benefit; the administrator of estate is obliged to preserve the substance and value of the assets. With respect to the topic of this article, it must be in connection with national assets.

\section{THE ASSET MANAGEMENT CONTRACT}

\subsection{The subjects of the contract}

Nvt. gives an exact enumeration who is allowed to become administrator of estate, in other words one of the subjects of the asset management contract. It varies on the owner of the assets: the Hungarian State, the local government or a legal person of a church. To summarize, the administrator of estate can be budgetary authority, public body, local government, ethnic government, association, ecclesiastical legal person, commercial entity, in which the state or the local government holds $100 \%$ of the participation interest separately or altogether, companies in which the $100 \%$ of the participation interest is owned by companies operating with state or local government membership, [8] among other legal institutes. The ministerial argument of Nvt. gives an explanation: the administrator of estate has various and strong rights, this person almost can be considered as an owner, therefore it is not worth to give this legal position to such legal entities those are run by natural persons and legal persons partially or fully. For example, it is possible that there are legal persons where the minority (counting the number of shares) has a bigger influence on decision-making for example with different kinds of preference shares regulated in Sections 3:230-3:235., 3:240. in Act V of 2013 on Civil Code (hereinafter referred to as CC).

Another subject of these contracts is that legal entity who exercises the rights and obligations of the owner over the assets. [9] 


\subsection{The objects of the contract}

The direct object ("human behaviour") of the asset management contract is the asset management itself, the indirect object is the property described by the act on national assets. This latter regulation has its bases in Fundamental Law of Hungary: The property of the State and of local governments shall be national assets. The management and protection of national assets shall aim at serving the public interest, meeting common needs and preserving natural resources, as well as at taking into account the needs of future generations. The requirements for preserving and protecting national assets and for the responsible management of national assets shall be laid down in a cardinal act. (This act is the Act CXCVI of 2011 on national assets.) The scope of the exclusive property and of the exclusive economic activities of the State, as well as the limitations and conditions of the alienation of national assets of outstanding importance for the national economy shall be determined in a cardinal act with regard to the goals [10] mentioned above. [According to Article T) (4) of the Fundamental Law, cardinal acts shall be acts, the adoption and amendment of which requires the votes of two thirds of the Members of the National Assembly present.] National assets with high importance from the aspect of national economy are non-marketable; [11] they cannot be transferred (unless otherwise is provided in Nvt.), cannot be encumbered (with some exceptions), cannot be pledged, cannot be established divided estate on them, on the other hand, the general rule is that they do not have to be utilized by concession. [12]

Since assets management contracts are contracts not only in their names, but also in their content, rules of law of obligations laid down in Civil Code must be applied. There are also some provisions of which application is excluded: for example, in that case if a legal act names the administrator of estate, rules of statutory obligation to contract in Section 6:71. of Civil Code [13] must not be applied.

The indirect object of asset management contract can be also rights that belong to the Hungarian State; based on the Act CVI of 2007 on state assets the rules of asset management for things must be applied. [14]

\subsection{The content of the contract}

As we examine the legal regulation in connection with the content of these contracts, the administrator of estate shall exercise the rights and obligations of the owner, and also the accounting obligations (as prescribed in the Act $\mathrm{C}$ of 2000 on accountancy), unless otherwise is provided in the legal act or in the asset management contract. But there are different rules compared to the owner:

- this person cannot transfer or encumber the managed assets with exceptions; therefore, he or she is allowed to encumber among others with beneficial use, servitude, but all of these must be based on law;

- the managed asset cannot be pledged;

- the administrator of estate cannot establish divided estate (divided estate means the ownership of the building belongs to its builder and not to the owner of the land);

- only central agencies are allowed to transfer the rights and obligations derived from asset management contract, but they also cannot transfer the rights and obligations in connection with real estate; [15] other legal entities who are allowed to become administrator of estate cannot transfer the rights and obligations derived from asset management contract;

- he or she cannot give owner's letter of consent in connection with the managed assets in case of court proceedings and authority proceedings with smaller exceptions.[16] 
The owner must pay fee for asset management, because asset management is free of charge only in cases of performance of public duties, providing public service towards the people and in necessary measure. [17]

Section 109 (1) and (2) of the Act CLXXXIX of 2011 on local self-governments of Hungary repeats the regulation of Nvt. in certain way: the municipal council may establish right of asset management things in ownership of local government based on Nvt. in connection with the transfer of public duties; the municipal council is allowed to enter into agreement only with persons who are defined as possible subjects in Nvt. Detailed rules of consideration of right of asset management, voluntary assignment, exercise of right of asset management and control of asset management must be regulated in local government ordinance; [18] these issues belong to the content of the contract. The administrator of estate must separate income and direct costs deriving from use and operation of the managed assets, this person must separate the expenditures and must tolerate the owner's control.

The special rules laid down in Act CVI of 2007 on state assets must be also taken into consideration if the national assets are state assets. The administrator of estate has also the same rights and obligations as they are determined in Nvt. This person must pay fee for assets management, must fulfil the obligations and use in that manner those are laid down in legal instruments and in the assets management contract. In case the administrator of estate does not perform these obligations, the person who exercises the rights and obligations of the owner over the assets can terminate the asset management contract effective immediately. [19] The parties are allowed to agree not to pay fee for assets management but to perform another kind of duty. [20] The administrator of estate is responsible for all the damages - those are because of use against the contract or legal instruments; except for proving that the procedure was with the care that is generally expected from administrator of estate of state assets under given circumstances. [21] This Government decree sets up a higher level of civil law liability for administrators of estate: it is based on fault, [22] therefore it has a subjective legal base, but the care is compared to other administrators of estate of state assets.

\section{CONCLUSION}

A wide range of things belong to those national assets, where asset management contracts must be entered into agreement. Due to this circumstance, it is worth to take a short outlook on the basic rules of this legal institute. Asset management and asset management contract themselves are not determined in Hungarian legal acts, therefore a proper notion should be created. Since this contract has its bases both in public law and private law, all the necessary definitions must be known and interpreted correctly. The act on national assets is considered to be a part of public law, but it consists of important regulation in connection with private law, and lots of rules can be understood only in the light of civil law. This article attempted to present the basic rules of asset management contract, one of the methods for public property management in Hungary.

\section{REFERENCES}

[1] B. Szabó, G., Illés, I., Kolozs, B., Menyhei, Á., Sándor, I. (2018) A bizalmi vagyonkezelés, 2nd edition, HVG-ORAC Lap- és Könyvkiadó, Budapest, pp. 19-22.

[2] See Nvt. Section 11 Subsection (8) a)

[3] See B. Szabó et al. pp. 19-22. 
[4] Németh, A., Sík, L., (1997) A vagyonkezelési szerződések típusai és biztositékai, in Pénzügyi Szemle, 1997, no. 2, p. 98.

[5] B. Szabó et al. p. 21.

[6] Németh, Sík p. 97.

[7] Sárközy, T., (1997) Az intézményes privatizáció befejezésének jogi technikájáról és a tartósan állami tulajdonban maradó vagyon kezelésének jövőbeli megoldásáról, in Gazdaság és Jog, 1997, no. 7-8, p. 17.

[8] Papp, T., (2018): Some question marks of private law on the state-owned companies in Hungary, in International and Comparative Law Review, 2018, vol. 18, no. 2, p. 216.

[9] Nvt. Section 3 Subsection (1) 17.

[10] Fundamental Law of Hungary (25 April 2011) Article 38 Subsections (1)-(2) http://njt.hu/ translated/doc/TheFundamentalLawofHungary_20190101_FIN.pdf (20.06. 2019.)

[11] See Nvt. Section 1 Subsection (2), Section 3 Subsection (1) 3.

[12] Papp, T., Balog, B. (2015) A koncessziós szerzödés, in Papp, T. ed. (2015) Atipikus szerződések, Opten Kiadó, Budapest, pp. 267-268.

[13] CC Section 6:71. [Statutory obligation to contract]

(1) Where an obligation to contract is prescribed by law, and the parties do not conclude the contract, the court shall have powers to establish the contract and to define its terms.

(2) By disclosing the necessary details and sending the necessary documents, the obligee may request the person who is subject to contracting obligation to make an offer. The obligor shall present his offer within thirty days following the effective date of the request.

(3) If the request for an offer does not contain the necessary details or documents, the obligor shall request these details and/or documents within fifteen days following the effective date of the request. In that case, the deadline for presenting the offer shall commence upon the provision of the missing details and/or documents.

(4) Conclusion of the contract may be refused if the obligor provides proof that he is incapable of performing the contract or there exists the right to withdraw from or to terminate the contract.

[14] Act CVI of 2007 Section 27 Subsection (3)

[15] Nvt. Section 11 Subsection (9)

[16] Nvt. Section 11 Subsection (8)

[17] Nvt. Section 11 Subsection (13)

[18] Act CLXXXIX of 2011 Section 109 Subsection (4)

[19] Act CVI of 2007 Section 27 Subsection (2a)

[20] Government Decree 254/2007. (X. 4.) Section 10 Subsection (3)

[21] Government Decree 254/2007. (X. 4.) Section 9 Subsection (4)

[22] If somebody's act does not meet with CC Section 1:4., it is the case of fault.

CC Section 1:4. [Principle of generally expected standard of conduct. Fault] (1) Unless otherwise provided in this Act, in civil law relations, one shall proceed with the care that is generally expected under the given circumstances.

See also Leszkoven, L. (2018) A polgári jog alapelvei, in Barzó, T., Papp, T. ed. (szerk.): Civilisztika I. Dialóg Campus Kiadó, Budapest, 36-38. 